also owe their brilliant colours to specific earotenoids of complex character; thus Actinia equina contains a very beautiful purple pigment, actinoerythrin, which is an ester ; the free violerythrin, $\mathrm{C}_{40} \mathrm{H}_{56} \mathrm{O}_{6}$, is characterized by the intense blue colour of its solution in organic solvents. Again, from Anemonia sulcata a still more oxygenated pigment, sulcataxanthin, $\mathrm{C}_{40} \mathrm{H}_{56} \mathrm{O}_{8}$, has been isolated.
Carotenoids have also recently been discovered in bacteria. Thus the purple rhodovibrio bacteria have been shown by Karrer to contain a series of probably six closely related pigments. Of these, rhodoviolascin, $\mathrm{C}_{42} \mathrm{H}_{60} \mathrm{O}_{2}$, has been clearly characterized, and constitutes the first known methylated xanthophyll.

(To be continued.)

\title{
The Earthquake Research Institute of Japan
}

\section{By Dr. Charles Davison}

$\mathrm{T}$ HE first Japanese earthquake known to us occurred in A.D. 416. For many years, the chronicle of its successors is naturally incomplete, but, with the nineteenth century, the entries become more frequent; how full they are is evident from Omori's studies of the after-shocks of the great earthquakes of 1830,1847 and 1854 . With the Yokohama earthquake of 1880 , the investigation of the earthquakes on modern lines began. Though not of great strength, the shock was the first to arouse the interest of the English professors then living in Tokyo. A few months later, the Seismological Society of Japan was founded by the late Prof. J. Milne, and the admirable work done by him and his colleagues during the next twelve years was continued and expanded by the Imperial Earthquake Investigation Committee and the Earthquake Research Institute.

For the next change, another earthquake was responsible, that of Mino-Owari on October 28, 1891. The widespread damage caused by this great earthquake led to the foundation in the following year of the Imperial Earthquake Investigation Committee, the aims of which were of a practical nature, namely, to discover, if possible, whether the occurrence of earthquakes can be foreseen, and to devise methods of lessening their destructive power. How great was the advance along the second line and how valuable were the contributions of the Committee towards our knowledge of earthquakes in general is clear from the journals that it published and especially from the long series of memoirs that appeared under the name of Prof. F. Omori.

In 1926, shortly after the publication of the valuable reports on the great earthquake of 1923 , the Investigation Committee ceased to exist, and its place was taken by the Earthquake Research Institute, with its home, as before, in the Imperial University of Tokyo. Why the change was made is not quite elear, unless it was felt that the work could be carried on more satisfactorily by younger men. The aim of the new Institute was stated to be scientific research on earthquakes. The first director was Prof. K. Suyehiro, who, on his death in 1932, was succeeded by Prof. M. Ishimoto. In its first year, the staff of the Institute consisted of thirteen members, several of whom had been connected with the Investigation Committee. During the last five years, the number of active members of the Institute was thirty-nine.

When the volumes issued by the Institute are compared with those of its predecessor, two welcome features are manifest-the extraordinary increase in the number of students of pure seismology, and the large number of memoirs written by two or more authors. During the first three years, the new Bulletin appeared twice a year, but in 1929 and after it was issued quarterly. By the end of 1936, fourteen ordinary volumes were completed, as well as three supplementary volumes containing papers and reports on the Sanriku seawaves of 1933, the typhoon of 1934, and the Formosa earthquake of 1935. Altogether, the seventeen volumes include 504 memoirs by ninety authors and number 7,646 pages with 1,023 plates. In the first four volumes, three out of every five papers were written in Japanese with summaries in English or French; but, in the last ten volumes, the ratio, fortunately for Western readers, fell to one in five.

Since the Institute began its work, there have been four great earthquakes in the Japanese empire-those of Tango in 1927, Idu in 1930, Sanriku in 1933 and Formosa in 1935-and, on each of these, series of valuable reports are printed in the Bulletin. Other earthquakes of less, but still destructive, intensity are also described in one or several papers, such as the Etigo earthquake of 1927, the Kaga earthquake of 1930, the Noto earthquake of 1933, the Idu earthquake of 1934, the Siduoka earthquake of 1935 and the KawatiYamato earthquake of 1936 . These are probably the most important Japanese earthquakes of the 
years 1924-36, but Western readers would be grateful if they could be supplied with an annual list of all the stronger Japanese earthquakes.

For an important section of the earthquakes, those that are sensible in Tokyo, the Institute provides valuable quarterly Seismometric Reports. In 1924, the capital was surrounded by a network of nine seismological stations at various distances up to 64 miles. By 1935, the number of stations had risen to thirteen, all within 83 miles of Tokyo. From the durations of the preliminary tremors at three or more stations, the position of the epicentre and the depth of the focus can be determined. During the twelve years 1924-35, the Reports contain the records of 766 earthquakes; thus, on an average, one earthquake was felt in Tokyo every 5.7 days. Of the total number, the position of the epicentre was estimated in 699 , or 91 per cent, and the depth of the focus in 553, or 72 per cent. All the epicentres are plotted on small maps, annually for the first seven years, quarterly for the last five. Most of the shocks were of slight intensity, and only four reached destructive strength at any one of the stations.

Similar observations, though on a less extensive scale, are made whenever a great earthquake occurs. Immediately after the Tango earthquake of March 7, 1927, members of the Institute were dispatched to the central district, and portable tromometers were installed at three stations near the epicentre on March 11 and 12, by which 1,327 after-shocks were recorded by the end of July 1928. Of these shocks, many were very slight, but 520 were registered at three stations, and the position of the epicentre was found for 482 shocks, and the depth of the focus for 477. Again, soon after the remarkable earthquake swarm at Ito began in the spring of 1930 , tromometers were erected at five surrounding stations and, later on, near the adjacent centre of the Idu earthquake of November 26, 1930. In both series, the earthquakes were so numerous, several hundreds sometimes occurring on one day, that no detailed list of them has been published.

In both the Tango and Ito districts, tiltmeters, designed by the present director, Prof. M. Ishimoto, were erected in the neighbourhood of the tromometers. It was found that, before even moderately strong shocks, a perceptible tilting of the ground was revealed by these instruments. Thus, it is not too much to hope that, before many years are past, such records may provide trustworthy forecasts of coming destructive earthquakes.

In no other country have re-surveys after great earthquakes been carried out with such frequency and method as in Japan. At the suggestion of the Institute, new lines of levelling were made by the Land Survey Department of the Japanese
Army across the central areas no less than five times after the Tango earthquake of 1927 and the Ito earthquake swarm of 1930 , and in many districts without the accompaniment of recent earthquakes. Re-triangulations of the central areas have been carried out after the Kwanto earthquake of 1923, and the Tango and Idu earth. quakes. The repeated levellings in some districts have shown that the crust is broken up into blocks, 4-6 miles across, and that each block moves more or less independently of its neighbours. The mapping of the blocks is perhaps most detailed in the Boso peninsula and the Kwanto plain, both forming parts of the region displaced during the great earthquake of 1923 .

Some of the phenomena of earthquakes have been closely studied, especially the remarkable seawaves of the Sanriku earthquake of 1933 and its predecessors, as well as the kase-tunamis or non. seismic seawaves that were raised by the great typhoon of 1934, and these studies have suggested precautions that, on future occasions, may lead to the saving of many thousand of lives. Luminous phenomena have been so widely observed with the Idu earthquake of 1930 and the Sanriku earthquake of 1933 that little doubt can now be felt as to their reality or their connexion, direct or indirect, with the earthquakes. Many curious and interesting observations have been recorded on the abundance of fishes caught after earthquakes, and on the relations between earthquakes and thunderstorms or the atmospheric pressure gradient. Though mainly concerned with theoretical studies, members of the Institute have also contributed to our knowledge of the vibrations of various types of buildings, of one story to eight stories in height. Many experiments have been made on artificial earthquake-waves, on the deformation of sand-masses by lateral pressure, and on seismic seawaves. The eruptions of volcanoes all over Japan have been investigated, especially those of the Komagatake in Hokkaido and of the Asama-yama in central Japan. Lastly, one of the most remarkable features of the fourteen ordinary volumes is the series of nearly one hundred mathematical memoirs, dealing as a rule with theoretical problems, but touching also on others of a more practical aspect in the vibrations of various types of buildings and the propagation of seawaves and seiches.

\section{REFERENCES}

Summaries of much of the work described above will be found in the following pages of NArYRE: Earthquake Research Institute, 119,$256 ; 125,868 ; 130,232,772 ;$ reports on Japanese earthquakes, $122,36,976-977 ; 123,295-296 ; 124,633 ; 129,404,766-767$ 132,681 ; 134, 31, 820 ; 137, 240; $138,171,353,1063$; earthquake. swarms, 126, 326, 971 ; 131,136 ; seismometric reports, 134,329 136, 919 ; 138, 252 ; crust-displacements, 119, 254; 126, 923-924; 130,$440 ; 132,356 ; 134,940 ; 135,273-274 ; 136,993 ; 137,281$, 1000 ; tilting of the ground, 119, $869 ; 124,633$; movements of crustblocks, 129, 321 ; 133, 536 ; luminous phenomena, 128, 155 ; 129, 27 ; 130,969 ; frequency of sunspots and earthquakes, 126,895 ; 'vibrations of buildings, 129, 693 ; typhoon of 1934, 136, 544; eruption of Komagatake, 128, 487 ; 